The Integration of Among (Instantiating) System in The Inclusive Education at Taman

Muda Ibu Pawiyatan Primary School Yogyakarta

Submitted: 26 August 2019, Accepted: 26 December 2019

AL-BIDAYAH: Jurnal Pendidikan Dasar Islam

ISSN: 2085-0034 (print), ISSN: 2549-3388 (online)

\title{
THE INTEGRATION OF AMONG (INSTANTIATING) SYSTEM IN THE INCLUSIVE EDUCATION AT TAMAN MUDA IBU PAWIYATAN PRIMARY SCHOOL YOGYAKARTA
}

\author{
Eka Tusyana, Wina Calista \\ Universitas Islam Negeri Sunan Kalijaga Yogyakarta \\ e-mail:ekatusyana07@gmail.com,winacalista21@gmail.com
}

\begin{abstract}
The research aim is to describe the integration of among systems in inclusive education at Taman Muda Ibu Pawiyatan Primary School Yogyakarta. This research utilized case study method with a qualitative approach. The data collection instruments were interview, observation, and documentation. The result indicates that among systems in inclusive education at Taman Muda Ibu Pawiyatan Primary School Yogyakarta is integrated into classroom and outing class learning activities. Among system in the classroom learning activity is integrated by teachers to not only provide material but also advise and habituation to students such as maintaining a good attitude to peers. Teachers apply the jigsaw method in learning, which is aimed to train regular students or students with special needs to implement the attitudes of being responsible, cooperative, and respecting other people's opinions. Teachers do not demand students with special needs to compare their ability with regular children to achieve scores based on Minimum Criteria of Mastery Learning (or usually called Kriterai Ketuntasan Minimal/KKM). They open the opportunity to students, especially they who have special needs at inclusive school to train their independence without continuously depending on guardian. In the among the system of outing class learning, teachers apply three systems, which are karawitan (playing a java musical instrument), dance art, and scout.
\end{abstract}

Keywords: Integration, Among System, Inclusive Education

\section{INTRODUCTION}

The education system in Indonesia, or what is usually known as National Education System is a whole component of education that is integrated connected to achieve a national education objective. ${ }^{1}$ The education system in Indonesia has been started since primary school, which is the value-based education system. Values which are embedded in students at primary school age are honesty, tolerance, discipline, etch which are furthermore integrated into the lesson. It demands Indonesian education to adjust itself with the general curriculum which is aimed to answer the demand of

\footnotetext{
${ }^{1}$ Act of RI No 20 Year 2003 On National Education System, Accessed on $7^{\text {th }}$ August 2019, from Https://Kelembagaan.Ristekdikti.Go.Id/Wp-Content/Uploads/2016/0 8/UU No20 Th_2003.Pdf.
} 
education in the present globalization era. Indirectly, the success of the education system which has been applied has not given the expected result. Some systems which have been applied in Indonesia until the present is unexpected to have a pure education system that was pioneered by one of the education heroes in Indonesia, Ki Hajar Dewantara. Ki Hajar Dewantara was one of the heroes in the education world who applied among the system. ${ }^{2}$ Among the system which is brought by Ki Hajar Dewantara is a theory that comes from his fruit of thought. ${ }^{3}$ In this case, among the system which is brought by Ki Hajar Dewantara has an aim to build students to become faithful and pious humans, physically or psychologically independent, intelligent and skilled, physically and psychologically healthy to be independent and responsible towards the nation wealth and humans in general. ${ }^{4}$

One inclusive school that applies among the systems on primary education in Yogyakarta is Taman Muda Ibu Pawiyatan Primary School, which is a part of Taman Siswa school that was established by Ki Hajar Dewantara. The term Taman Siswa is the first education, which applied among the systems by Ki Hajar Dewantara. Taman Muda Ibu Pawiyatan Primary School is an inclusive school that integrates among the systems that were brought by Ki Hajar Dewantara. Therefore, it has special characteristic during the learning process, which more emphasizes on nobility towards the students.

Among system which is implemented at inclusive school will strengthen the relationship between teachers and all students without looking at students' differences. It is appropriate with the objective of inclusive education, which is to provide friendly education without discrimination to all students. It is relevant to the explanation. ${ }^{5}$ Inclusive education as an education which accepts regular students and them with special needs in which the school is demanded to be able to creating a friendly education environment. ${ }^{6}$

In this thing, teachers or guardians who are in Among System of Ki Hajar Dewantara have a role not only to transfer knowledge but become students' parents at school. Therefore, teachers should be a great model and figures who can build a secure, comfortable, and peaceful learning environment for all students, including students with

\footnotetext{
${ }^{2}$ Moh.Yamin, Menggugat Pendidikan Indonesia (Yogyakarta: Ar-Ruzz Media, 2009), p. 173.

${ }^{3}$ Suparto Rahardjo, Ki Hajar Dewantara Biografi Singkat, (Yogyakarta: Garasi, 2009), p. 9.

${ }^{4}$ Suparto Rahardjo, Ki Hajar Dewantara..., p. 72.

${ }^{5}$ Satmoko, Sekolah Alternatif, (Jakarta: Pedar Kindy, 2016), p. 112.

${ }^{6}$ Nini Subini, Pengembangan Pendidikan Inklusif, (Yogyakarta: Maxima, 2014), p. 89.
} 
special needs. It is in line with the definition of inclusive education, which respects and appreciate diversity. ${ }^{7}$

However, on the implementation, not all-inclusive education can build friendly education at school. In Indonesia, there are some problems which are found; one of them is discrimination. The discrimination occurs because of the most noticeable difference of the group. The minority often experiences discrimination. Most of them are usually disabled, cultural minorities, or poor people. ${ }^{8}$ It is opposite of Act Number 20 of 2003 Article 4 Paragraph 1 on National Education System, so education in Indonesia is held democratically, reasonably, and indiscriminately by prioritizing human rights, religious and cultural values, and nation pluralities. ${ }^{9}$ Therefore, among system in inclusive education is expected to be an education system which can minimize the discrimination at school. It is written on the mandate of education, according to Ki Hajar Dewantara. In order to genuinely know how the implementation of among system is, this research is aimed to see how among system is integrated into inclusion education at Primary School of Taman Muda Ibu Pawiyatan Yogyakarta.

\section{RESEARCH METHODS}

The method that was utilized in this research was case study and descriptive method with a qualitative approach. The objective is to explain facts and population characteristics systematically, factually, and accurately. ${ }^{10}$ Meanwhile, the result of the analysis of the qualitative descriptive approach is in the form of the description on the situation, which is observed in the form of narrative. ${ }^{11}$

The method which was utilized in this research was descriptive qualitative in which the researcher describes the phenomenon related to the integration of among system in inclusive education at Taman Muda Ibu Pawiyatan Primary School Yogyakarta. The research subjects were all school members in Taman Muda Ibu Pawiyatan Primary School Yogyakarta.

\footnotetext{
${ }^{7}$ Ibid, p. 99.

87.

${ }^{8}$ Dedy Kustawan dan Budi Hermawan, Model Inklusif Ramah Anak, (Jakarta: Luxima, 2013), p.

9 Act of RI Number 20 Year 2003 on National Education System, (Bandung: Citra Umbara, 2016), p. 6.

10 Arifi, Penelitian Pendidikan Metode dan Paradigma Baru, (Bandung: Rosdakarya, 2012), p. 56.

11 Nana Sudjana dan Ibrahim, Penelitian dan Penilaian Pendidikan, (Bandung: Sinar Baru Algensindo, 2014), p. 187-198.
} 
Meanwhile, data collection techniques which were utilized in this research were interview, observation, and documentation. The interview was one of information data collection techniques which were done by using question and answer between interviewer and source. The interview which was done in this research was a direct interview. Since this interview was performed directly to teachers, and one of them was School Principal of Taman Muda Ibu Pawiyatan Primary School Yogyakarta.

The observation was monitoring and registry towards phenomenon which occur in the research object. The observation which was performed in this research was direct observation because the researcher directly observed and registered the occurrence based on the object that was related to the integration of among system in inclusion education at Taman Muda Ibu Pawiyatan Primary School Yogyakarta.

Documentation was an information collection method that was obtained from documents, such as written relic, archives, certificate, diploma, rapport, photo, or data folder. Documentation, which was utilized in this research, was the photo taken during the research process that is related to among system integration in inclusive education at Taman Muda Ibu Pawiyatan Primary School Yogyakarta.

Data analysis which was utilized in this research was: data collection of activities that were performed during the observation, interview, and documentation in inclusive education related to among system integration at Taman Muda Ibu Pawiyatan Primary School Yogyakarta; data reduction was a data selection process which was performed by the researcher by summarizing the data which is relevant with the integration of among system in inclusive education at Taman Muda Ibu Pawiyatan Primary School Yogyakarta; data display was an organized information presentation that provided conclusion drawing and action-taking, while the data presentation which was performed in this research was in the form of narrative text which explained the integration of among system in inclusive education at Taman Muda Ibu Pawiyatan Primary School Yogyakarta; conclusion drawing was the final step of research process. Conclusion drawing is brief, dense, and precise related to the research objects of among system integration in inclusive education at Taman Muda Ibu Pawiyatan Yogyakarta. 


\section{RESULT AND DISCUSSION}

Based on this research, among system which is implemented in inclusive education is found at Taman Muda Ibu Pawiyatan Primary School, which is implemented by teachers who have the role as the guardian through school activities and classroom or outing class learning.

\section{Among System of Classroom Learning}

Among system was the first established by Ki Hajar Dewantara. Ki Hajar is as one of the academicians or education figures in Indonesia. Among system is a media which is utilized in education and maintain attention to develop children's physical and psychological growth in nature. ${ }^{12}$ In this system, teaching means education children to become spiritually independent humans.

According to language, among systems comes from two words: "system" and "among." The system is defined as a method or implementation pattern. In the external definition, systematic is also defined as a group of interrelated components that have the function to reach the objective that has been set. The concept of "among" comes from Sanskrit, which means taking care, looking after, and keeping. ${ }^{13}$ The word "among" means the root "mong" which includes momong, among, and ngemong. ${ }^{14}$ Momong means look after sincerely and attentively and give the example of a good habit.

In the Javanese language, among means giving an example or model towards good thing without taking children's rights so that they can grow and develop with an independent spiritual vibe. In the Javanese language, ngemong means the process of looking after and protecting so that children can develop themselves to become a responsible, discipline, and obedient towards values which are prevailed in their environment.

According to Muhammad Nur Wangid, among system is a pattern which can be used by education so that teachers can pay attention to students' interest and needs. ${ }^{15}$ In this case, among system which is implemented at Taman Muda Ibu Pawiyatan Primary

12 Ki Hajar Dewantara, Pemikiran, Konsepsi, Keteladanan, Sikap Merdeka, (Yogyakarta: Majelis Luhur Persatuan Taman Siswa, 2013), p. 48.

${ }^{13}$ Andri Bob Sunardi, BOYMAN Ragam Latih Pramuka, (Bandung: Nuansa Muda, 2006), p. 62.

${ }^{14}$ Suparto Raharjo, Ki Hajar Dewatara, (Yogyakarta: Garasi, 2009), p. 71.

15 Muhammad Nur Wangid, "Sistem Among pada Masa Kini Kajian Konsep dan Praktik Pendidikan” dalam Jurnal Kependidikan 39, no. 3. (2009). 
School means that teachers are models and parents' replacement at home who have duties to protect, keep and give a good example such as speaking honestly, polite, respect older people and love each other. Taman Muda Ibu Pawiyatan Primary School as the inclusive school has students with special needs with various disability types.

Based on this research which was performed at Taman Muda Ibu Pawiyatan Primary School, it is found that the school pays attention to each student's needs and ability, whether it is related to academic, physical, psychological, or capability. Since teachers understand that every student has different characteristics, natures, and innate. ${ }^{16}$ It is appropriate with the result of research which was performed by Widya Noventra on among system that indicates it is appropriate to be a method to educate and build an independent spiritual so that students are more courageous to study what is desired by them because this education pattern gives independence and freedom to students as their nature. ${ }^{17}$

\section{Integration of Among System in Inclusive Education at Taman Ibu Pawiyatan Primary}

Among the systems which is implemented by teachers (guardian) that have been started from grade one. On grade one, teachers familiarize and advise students to behave well to their peers, including students with special needs at inclusive school, so that kinship attitudes among regular students or students with special needs. The action shows good cooperation among them, such as regular students, assist students with special needs when they experience difficulty in learning, such as doing an assignment, and they do not discriminate their playmate. Teachers have indeed embedded it since they are on grade one.

If it is seen from inclusive education, among system which is applied in the learning process is different from the process of public school learning. One of the learning forms of among system, which is brought by Ki Hajar Dewantara is to teach

\footnotetext{
11.00 WIB.

17 Widya Noventari, "Harmonisasi Nilai-Nilai Pancasila Dalam Sistem Among Sesuai Dengan Alam Pemikiran Pendidikan Ki Hajar Dewantara”, dalam Jurnal Pancasila dan Kewarganegaraan 1, no. $1,(2016)$.
}

${ }^{16}$ Observation at Taman Muda Ibu Pawiyatan Primary School Yogyakarta on $7^{\text {th }}$ August 2019 at 
students studying in the group to enable them building social interaction with their peers. $^{18}$

The Guardian teacher on grade five implements it in the learning process by first, among system in group learning is done by applying the jigsaw method in classroom learning between regular and students with special needs. In its application, the teacher combines both types of students. It is aimed to train them manifesting responsibility, cooperation, and respect for other people.

Second, in the classroom learning process, the guardian teacher does not demand students with special needs to equalize their ability to regular students to achieve scores based on the Minimum Criteria of Mastering Learning (KKM), which is prevailed at school. Therefore, guardian teachers reduce the indicator of learning outcome achievement for students with special needs. It is relevant among systems which is prevailed at school where students are given freedom based on the capability of students with needs at inclusive school. However, giving freedom does not mean guardian teachers' freedom in taking action at school. As the slogan, tut wuri handayani, among system is when teachers provide an opportunity to students, especially students with special needs at inclusive school, to train their independence without continuously depending on guardian teachers or other people. As embedded at Taman Muda Ibu Pawiyatan Primary School as an inclusive school, which more emphasizes on character values such as independence, honesty, and responsibility.

In line with the previous explanation, it is relevant to Mohamad Said in Fikri Fridiansyah's journal that explains the foundation among the systems is on the slogan Tutwuri Handayani which means giving freedom, opportunity, attention, and development that enable children to have self-initiative as their personal experience and nature. Tutwuri Handayani is the system that must be possessed by guardian teachers. Behaving as tutwuri means guardian teachers should be able to give freedom to students to make everything as the prevailing norm. Behaving as Handayani means guardian teachers should give good influence power if students apply their freedom beyond the existing requirements. ${ }^{19}$

${ }^{18}$ Suparto Raharjo, Ki Hajar Dewantara ..., p. 73.

19 Fikri Firdiansyah, "Pendekatan Sistem Among Pada Proses Pembelajaran Di SMK Taman Siswa Kediri Tahun 2006-2012 dalam Dinamika Modernisasi" dalam Jurnal Avantara Pendidikan Sejarah 1, no. 3. (2014). 
It is relevant with the objective of among system which is brought by Ki Hajar Dewantara to build students to be believing and cautious, psychologically and spiritually free, have noble mind and character, smart and skilled, mentally and psychologically healthy so that they can be independent and responsible societies on the welfare of nation and humans in general. ${ }^{20}$

\section{Learning Among System Outside the Class}

Among system which is implemented by Taman Muda Ibu Pawiyatan Primary School does not only covers learning process but juga school activities such as karawitan (a Javanese musical instrument), dance, and scouting.

First, karawitan activity is one of the activities that must be followed by all students of grade I to 6 at Taman Muda Ibu Pawiyatan Primary School. Karawitan of each class is scheduled once a week. The first stage, which is done by karawitan teacher, is choosing songs with themes such as patriotism, friendship, parents, or teachers. In karawitan activity, teachers make a fun learning and choose materials which are easily understood by students to practice it using gamelan. During the learning process, students are seen enthusiastically and are not border because regular students and they with special needs can express themselves through singing or playing gamelan. Based on the observation result during karawitan activity, regular students can play the gamelan instrument well. It can be seen when regular students assist other regular students or them with special needs who have not known how to play gamelan. In this karawitan activity, teachers instruct to play gamelan and assist students who find difficulty.

Second, among sytem in dance act at Taman Muda Ibu Pawiyatan is a mandatory activity that must be followed by stuents. The dance art is something that can motivate, build intellectual, activity, feeling and motoric movements of students. Students who know dance art will have more subtle soul. Dance art learning to refine the soul is also presented by Dance Art tutor, Hani Setiawati, that "dance art encourages students to master dance movements and foster refinemind and independence of children."

\footnotetext{
${ }^{20}$ Suparto Raharjo, Ki Hajar Dewantara ..., p. 72.
} 
The benefits of dance art in inclusive education is aimed to develop cooperation, and build interaction among students or dance teacher. Besides, among system also provide students to freely express through dance movements and embed patriotism, develop children's personality, and enliven cultural values. In line with the statement of Chatam, Ar inYoyok Sumargono's journal, which stated, "It is vital to introduce dance art in children's world as early as possible, especially on primary school age students. Schools should continuously maintain and develop art in learning for children's personality development." 21

Third, among system in scouting activities is defined as an education activity which is performed by giving a freedom to students to express themselves, move, and able to act freely without following a requirement or coercion. It certainly has an objective to train and develop students' self confidence and each individual's creativity. ${ }^{22}$ Among the system in scouting activity is performed at Taman Muda Ibu Pawiyatan Primary School to strengthen family atmosphere by scouting training of regular students or them with special needs that follow the activity.

The procedure of implementing among system which is brought by Ki Hajar Dewantara is emphasizing guardians on creating not rigid such as asking to study while playing. ${ }^{23}$ This procedure is implemented in scouting activity at Taman Muda Ibu Pawiyatan Primary School that train students attentively, softly and give an good model towards the members. Scouting education activity is performed based on among system which demands the traner to act and behave positively towards his/her attitude. As mandated by Ki Hajar Dewantara that scouting leader must reflect the attitude of Ing Ngarsa Sung Tuladha which means in the frontline to give an example, Ing Madya Mangun Karsa which means in the middle to give a spirit and Tut Wuri Handayani which in the bact to support.

\section{CONCLUSION}

Among system is the method of educating children based on their independence and freedom so that they can grow as their nature. Among systems should be a method

\footnotetext{
${ }^{21}$ Yoyok Sumargono, "Pelaksanaan Pembelajaran Among Untuk Pendidikan Budi Pekerti Luhur di Sekolah Dasar" dalam Jurnal Pendidikan Dasar Nusantara 1, no. 1. (2015).

22 Jana. T. Anggadireadja, et.al. Kursus Mahir Dasar untuk Pembina Pramuka, (Jakarta: Kwartir Nasional Gerakan Pramuka, 2011), p. 81.

${ }^{23}$ Ibid, p. 73.
} 
of educating to create free souls so that students are more courageous in inclusive education at Taman Muda Ibu Pawiyatan Primary School, which is implemented through classroom or outing class learning activities such as karawitan, dance art and scouting. Among system which is implemented by teachers since primary age on inclusive education in the school environment will build a model and social attention between regular and special needs students. The foundation of among system will help students to become humans who are religious and cautious, physically and spiritually free, virtuous, intelligent and skilled, and physically and spiritually healthy.

\section{REFERENCES}

Act of Republic of Indonesia No. 20/2003 On National Education System, Accessed on $7^{\text {th }} \quad$ August 2019, from Https://Kelembagaan.Ristekdikti.Go.Id/WpContent/Uploads/2016/0 8/UU_No20_Th_2003.Pdf.

Anggadireadja, Jana. T., et.al. (2011). Kursus Mahir Dasar untuk Pembina Pramuka, (Jakarta: Kwartir Nasional Gerakan Pramuka).

Arifi. (2012). Penelitian Pendidikan Metode dan Paradigma Baru, (Bandung: Rosdakarya).

Dewantara, Ki Hajar. (2013). Pemikiran, Konsepsi, Keteladanan, Sikap Merdeka, (Yogyakarta: Majelis Luhur Persatuan Taman Siswa).

Firdiansyah, Fikri. (2014). "Pendekatan Sistem Among Pada Proses Pembelajaran Di SMK Taman Siswa Kediri Tahun 2006-2012 dalam Dinamika Modernisasi" dalam Jurnal Avantara Pendidikan Sejarah 1, no. 3.

Kustawan, Dedy \& Budi Hermawan. (2013). Model Inklusif Ramah Anak, (Jakarta: Luxima).

Noventari, Widya. (2016). "Harmonisasi Nilai-Nilai Pancasila Dalam Sistem Among Sesuai Dengan Alam Pemikiran Pendidikan Ki Hajar Dewantara", dalam Jurnal Pancasila dan Kewarganegaraan 1, no. 1.

Rahardjo, Suparto. (2009). Ki Hajar Dewantara Biografi Singkat, (Yogyakarta: Garasi).

Satmoko. (2016). Sekolah Alternatif, (Jakarta: Pedar Kindy).

Subini, Nini. (2014). Pengembangan Pendidikan Inklusif, (Yogyakarta: Maxima).

Sudjana, Nana. \& Ibrahim. (2014). Penelitian dan Penilaian Pendidikan, (Bandung: Sinar Baru Algensindo). 
Eka Tusyana, Wina Calista

Sumargono, Yoyok. (2015). "Pelaksanaan Pembelajaran Among Untuk Pendidikan Budi Pekerti Luhur di Sekolah Dasar" dalam Jurnal Pendidikan Dasar Nusantara 1, no. 1.

Sunardi, Andri Bob. (2006). BOYMAN Ragam Latih Pramuka, (Bandung: Nuansa Muda).

Wangid, Muhammad Nur. (2009). "Sistem Among pada Masa Kini Kajian Konsep dan Praktik Pendidikan" dalam Jurnal Kependidikan 39, no. 3.

Yamin, Moh. (2009). Menggugat Pendidikan Indonesia (Yogyakarta: Ar-Ruzz Media). 
The Integration of Among (Instantiating) System ...

AL-BIDAYAH, Volume XI, Number 2, December 2019| 357 